\title{
Noticing Students' Thinking and Quality of Interactivity During Mathematics Learning
}

\author{
Ratu Ilma Indra Putri \\ Sriwijaya University \\ Palembang, Indonesia \\ ratu.ilma@yahoo.com
}

\author{
Zulkardi \\ Sriwijaya University \\ Palembang, Indonesia \\ zulkardi@gmail.com
}

\begin{abstract}
Teachers have a role to implement the new curriculum in school. Therefore they need to support especially in orchestra learning process in the classroom. The goal of this research is to support mathematics teachers implement new curriculum or curriculum 2013 in the school. Such support, for examples, providing teachers with good designed example curriculum materials and giving a teacher professional development for implementing the curriculum materials in the classroom practices. Hence, curriculum learning materials, in this case in Numbers is needed to be designed, and a design research approach is used. Three steps of the design research approach were used namely analysis and design, experiment and retrospective analysis. Furthermore, PMRI schools students primary school grade five in Palembang Indonesia were used as participants in the research. Then teachers are going to use those materials in the classroom practices. Noticing student's thinking and quality of interactivity of students during learning with social norms was the main activities in this research. The results of a questionnaire were slightly differenced with observation results. During the learning process, the teacher was not optimal in giving a chance to explore their mathematical thinking. This situation can be seen that the teacher only focuses on what the solution not on why and how to get a solution.
\end{abstract} PMRI

Keywords-: Noticing, Social Norm, Socio-mathematical Norm,

\section{INTRODUCTION}

Up to now, the learning process still uses a conventional approach in Indonesia. Using this approach teachers dominate the lesson and focusing more on concepts in step of competencies. During the learning process, students more listening less thinking [1], [2]. This situation is not relevance with the new curriculum in which learning focus on students. New curriculum aims at developing student's competencies such as mathematical thinking. Curriculum 2013 has a role in guiding students to be able to solve the problem by observing, questioning, listening and communicating the solution to the problem. Furthermore, students are expected to have a positive attitude on how to use mathematics in their daily life, such as curiosity, attention, motivation, as well as more confidence to learn mathematics [3]. Therefore using social norm in the classroom is very important [4]; [5].

Pendidikan Matematika Realistik Indonesia (PMRI) is an innovation in mathematics education in Indonesia. It was initiated by the group of teacher educators and mathematicians in the year 2001 [6]. Since the start of the PMRI project, many programs have been brought about to improve the effectiveness of mathematics teaching in Indonesia [7]. It is a new way of teaching and learning aiming at better results for the students. It is now a growing movement and shows promising results [6]; [7]. The PMRI project focused on developing an educational approach emphasizing the use of context that allows students to realize what they are doing and stimulating conversations about the thinking process of the students [6]; [2]. It developed an alternative way of teaching and learning in Indonesia aimed at better student' results. The PMRI project increased the awareness by policy makers, textbook authors, teacher educators, and teachers to create meaningful learning processes in learning mathematics [2]. However, both classroom observations and experiences of master students researching the effects of a newly designed realistic learning materials [5]; [8], show that traditional Indonesian classroom norms are hindering the development of new educational practices. Classroom observations show that most Indonesian students are neither stimulated nor able to argue and justify their solution fluently. An example of research on PMRI approach in Palembang [5], stated teachers can implement PMRI approach in the classroom. However they still have a problem in managing the interactivity during the learning process.

Realistic Mathematics Education (RME) was adapted by using Indonesian context [9]. PMRI, therefore, still use the philosophy of RME that mathematics is a human activity. Also, three principles of RME are still used as the principle of PMRI. They are guided reinvention through mathematization; use of didactical phenomenology and self-developed models [10]. Furthermore, PMRI also uses the five characteristics of RME. This principle and characteristics of RME are used as a guide to developing curriculum materials. In other words, to design or redesign curriculum materials based on the realistic mathematics education approach, five characteristics of RME should be represented. The steps are [9]: (1) situating the intended material in reality which serves as source and as area of application, starting from meaningful contexts having the potential to produce mathematical material; (2) intertwining with other strands or units such as fractions and proportions; (3) producing tools in the form of symbols, diagrams, and situation or context models during the learning process through collaborative effort; (4) learning through construction is carried 
out by arranging student activities, so they can interact with each other, discuss, negotiate, and collaborate; and (5) encouraging pupils to follow this kind of constructional activity by giving them an assignment that leads to free productions.

Exemplary lesson materials refer to learner materials and teacher guides. They can be used as a learning trajectory for teachers in the RME classrooms. They usually consist of the following main components: content materials, learner and teacher activities, and assessment. RME materials are associated with real-life activities where domain-specific, situational knowledge and strategies are used within the context of a genuine situation. A variety of contextual problems is integrated into the curriculum right from the start. But, the sequence of the contextual problems has to guide pupils to the mastery of a mathematical concept. Furthermore, the difficulty level of the contextual problems should be appropriate for the goals of a particular mathematics topic.

Characterized three levels thinking skills in mathematics education: lower level, middle level, and higher order level [11]. These three levels of thinking skill can be similar to the three "competency classes" that are used by the PISA to assess mathematical literacy. The three competency classes consist of: (1) simple computation; (2) connections; and (3) mathematical thinking...[12].

Mathematical thinking as one of the mathematical competencies can be described as follows [12]: (1) Posing questions characteristic of mathematics-Does there exist...? If so, how many? How do we find...? ; (2) Knowing the kinds of answers that mathematics offers to such questions; (3) Distinguishing between different kinds of statements (e.g., definitions, theorems; conjectures, hypotheses, examples, conditioned assertions); and (4) Understanding and handling the extent and limits of given mathematical concepts.

In RME, the assessment functions not only in the margin of instruction, but it is also an integral part of the instructional process [11]. Ideally, during assessment activities, pupils can show their abilities to solve problems using different strategies. Moreover, through interactive discussions during the learning process, they can learn different strategies developed by other pupils. The strategies used by pupils can be good feedback for the teachers to improve the next lesson. Also, pupils learn to use various strategies for solving problems during the exams.

Assessment can be conducted in the classroom using strategies both during the interaction process (formative), and products of their solutions (summative). In RME, both the process and product are considered important. Hence, these two assessment strategies should be applied in tandem when developing assessment materials.

Thinking mathematically is about mathematics process not about the branch of mathematics [13]. Students think mathematically when teachers give a problem or a task in the classroom practice. Mathematical thinking can be improved by practice with reflection. Categorize ways of improving mathematical thinking of students in the school namely (1) tackling questions carefully; (2) reflecting on this experience; (3) linking feelings with action; (4) studying the process of resolving problems; and (5) noticing how what you learnt fits with your experience [13].

Moreover, noticing is categorized into three components as follows.

1. Attending to children's strategies or describing in detail what the children said and did in response to this problem.

2. Interpreting children's understandings by explaining what you learned about these children's understandings.

3. Deciding how to respond by children's understandings. Pretend that you are the teacher of these children. What problem or problems might you pose next?

Noticing is a regular activity of teaching. Noticing effectively is both complex and challenging. To be a professional teacher is to the need to notice and be sensitive to the experiences of pupils. To develop your professional practice, you must first develop your sensitivities and awareness.

The role of the RME teacher in the classroom is [10]: a facilitator, an organizer, a guide and an evaluator. The roles of RME teachers can be seen from the following common teaching-learning processes.

1. Facilitate pupils with a contextual problem that relates to the topic as a starting point.

2. During an interaction activity, give the pupils a hint, for instance by drawing a table on the board, guiding the pupils individually or in a small group in case they need help.

3. Let the pupils find their solution. This means that pupils are free to make discoveries at their level, to build on their experiential knowledge, and perform shortcuts at their pace.

4. Organize and stimulate the pupils to compare their solutions in a class discussion. Ask the pupils to communicate, argue and justify their solutions. The discussion refers to the interpretation of the situation sketched in the contextual problem and also to focus on the adequacy and the efficiency of various solution procedures.

5. The role of pupils in RME classroom is mostly that they work individually or in a group, they are active and should be more or less independent, they can not turn to the teacher for validation of their answers or directions or a standard solution procedure, and they are asked to produce free creations or contributions.

Mathematics education in Indonesia has been changing: from instruction as the 'transmission of knowledge' toward 'learning as the construction knowledge' [15]. Results of implementation of PMRI are problem-centered and interactive mathematics education. However problem-centered and interactive classroom, require a difference didactical contract that is classroom social norms, such as the obligation to think for students themselves, to explain and to justify their solution, to try and understand other student's reasoning, to ask question about the explanations they do not understand, challenge arguments they do not agree with [15]. 
According to [5], the need of helping teachers in Indonesia to develop norm in PMRI classroom to encourage them to move from perceiving the teacher as the provider of knowledge to the teacher as a knowledgeable orchestrator. Social norms classroom is a challenging practice for both teachers and students because in many classrooms are not yet accepted as part of the classroom culture [2]. The social norms guide the class on the normative expectations of interactions such as the need to not only provide an answer but also explanations that lead to the answer. Classroom situation in Indonesia still noisy due to there is no rule from the teacher how to answer the question. Therefore it is important to conduct a workshop to introduce social norms to teacher norms. Social norms and socio mathematical norms are accepted as a useful tool in analyzing and mathematical learning in classrooms [16]; [15. Students learn to take turns in sharing their ideas and in listening to each other [6]. Another challenge in Indonesian classrooms is to change the common practice whereby the teacher gives final judgment to students' answers as right or wrong.

Professional development of teachers about new curriculum is focused only on content materials and how to implement the materials in the classroom. However, in a short time, training does not focus on the social norm. One of the ways to introduce a social norm to the teachers is to give special training on how to use social norm and socio mathematical norm [17]. Putri has conducted such program aims at teachers can know and implement the norm in their classroom. In this paper will describe the implementation social and socio mathematical norm by PMRI teacher in Palembang.

Students learn to take turns in sharing their ideas and in listening to each other [6]. Another challenge in Indonesian classrooms is to change the common practice whereby the teacher gives final judgment to students' answers as right or wrong. In PMRI classrooms, teachers are encouraged to invite students to take an active role in making this decision using teacher's prompts and other students' questions; they are guided to determine if their answers are acceptable.

\section{METHODS}

This research involved 30 students fifth grader from one of the PMRI school in Palembang. The teacher, Miss Wina is the young teacher have been involved in PMRI project since 2012. A year before, Miss Wina was one of the participants in professional development in using social and socio mathematical norm.

This research used design research method, which is one of a qualitative approach. Design research aims to develop local instruction theory that is based on existing theory (theorydriven) and experiment empirically (empirically based) through cooperation between researchers and teachers to improve the relevance of research by policy and education practice [4]. There are three stages in the research design, those are: preparing for the experiment, the design experiments, and the retrospective analysis [14], [19].

\section{RESULTS AND DISCUSSION}

Research shows that the teacher was able to use social and socio mathematical norm in her class. However, it is still needed guidance for the teacher to implement in an optimal way. The lesson uses four problems about proportion. In this paper only describe the fourth problem, because it shows the conflict among students to solve it.

Problem: Car A use 5-liter gasoline for $70 \mathrm{Km}$, while car B use 4 liters for $60 \mathrm{Km}$. Which car is more economic? Explain your reasoning!

From the problem above, the teacher divided students into five groups; each group has five students. During discussion some group has difficulties in solving the problem, for instance, group 2 and four still had difficulties in finding which car is more economic. They assume the economic car is if the result (14 or 15) of the problem is small, as figure 1 .

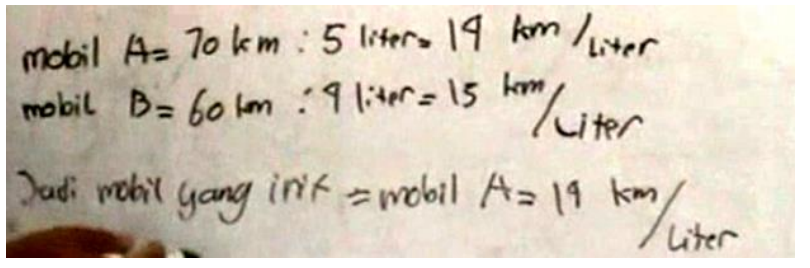

Fig 1. One of student solution

The following conversation

Student : $70 \mathrm{Km}: 5$ liter $=14 \mathrm{Km} /$ Liter

Student : While car B is $60 \mathrm{Km}$; 4 liter $=15 \mathrm{Km} / \mathrm{Liter}$

Teacher : So

Student : so, car A is more economic than car B which covers $14 \mathrm{Km} /$ Liter

Teacher : Ok stop, please...

Teacher : We have seen the answer from I am. He said that car A more economic than car B because it covers 14 $\mathrm{Km} /$ liter which further than that of $\mathrm{A}$.

The conclusion is students can solve the problem, although there is still have problems. Because some times students could not communicate their answer. So the teacher has the role to guide students thinking using social and socio mathematical norms.

From the conversation above, it shows the teacher has used socio mathematical norm. However, the teacher only focuses on what is the solution of the student not on why and how student finds the solution. Even the teacher explain the strategy how to solve the problem. This situation shows the teacher still not able to use socio mathematical norm to see student mathematical thinking.

During the group discussion, some students ask the meaning of economic in that problem. They have the wrong assumption about economic in the problem. They assume that economic means the smaller value from the computation. This result showed that students are not able to understand the context. Therefore, the reason behind the choice of economic 
price was not clear. Group 3 was able to solve the problem correctly; this will be discussed below.

Student 1 : Now we must find 1 liter equals how many $\mathrm{km}$ ?

Student 2 : A liter equals to $15 \mathrm{~km}$

Student $3: 20 \mathrm{~km}$ equals to 4 liter

Student 4 : After this, A liter equals to $15 \mathrm{~km}$

Student 1 : This more economic, right?

Student 1 : Is it right mom?

Teacher : Which one is more economic?

Student 1 : This is car A

Teacher : This is car A and this is car B, It was fill up by a liter of gasoline

Teacher : be going on

Teacher : The car A will stop at $14 \mathrm{Km}$ then B will stop 15 $\mathrm{Km}$

Teacher : Estimate. Which one is more economic between car A and B?

Student 2 : The car B mom

Teacher : Why

Student 1 : because the other one is bigger

Teacher : more .... What more?

Student 1 : it more than another one

Teacher : If car A will but the other one still going on. So what do you think?

Teacher : is more ... more?

Student 1 : more economic.

After the group discussion, the process continues to the whole class discussion. They have to present their solution and give reasoning in front of the class. The first social and Socio mathematical norm are given by the teacher are to make students responds in their group with solving the problem correctly, and students learn to take turns in sharing their ideas and in listening to each other. Communication is the second social and Socio mathematical norm where students have to explain how they find a solution.

\section{The TEACHER ACTIVITIES USING SOCIAL AND SOCIO MATHEMATICAL NORM}

In PMRI classrooms, teachers are encouraged to invite students to take an active role in making this decision using teacher's prompts and other students' questions; they are guided to determine if their answers are acceptable. To investigate the role of the teacher in noticing students' thinking and using social norms to support student learning mathematics in the PMRI classroom practices.

First, we choose a teacher who wants to implement social and Socio mathematical norms, and then making lesson material in topic proportion, using observation to know the role of a teacher in noticing students' thinking and using social norms to support student learning mathematics.

Second, analyze classroom observation using video, and to interpret a teacher in noticing students' thinking and using social and socio-mathematical norms. In the process activity of class discussion, the teacher noticed that she guide how to solve the problem. She invited students to ask questions based on unresolved questions or confusions they had during the discussion. In this case, the teacher set another social norm for students to participate by bringing any unresolved problem.

Finally, Using questionnaire, teacher reflects on her change. Table 1 shows, the teacher reflect of Socio-mathematical norm.

TABLE I. ANALYSIS OF THE TEACHER USE SOCIAL MATHEMATICAL NORM

\begin{tabular}{|c|c|c|c|}
\hline No. & Problem & Before & After \\
\hline 1. & How to Teach & $\begin{array}{l}\text { The teacher passive, } \\
\text { because students do } \\
\text { not explore the idea } \\
\text { The teacher does not } \\
\text { involve students to } \\
\text { resolve the existing } \\
\text { problems }\end{array}$ & $\begin{array}{l}\text { The teachers active } \\
\text { because students can } \\
\text { explore the idea } \\
\text { The teacher has } \\
\text { involved students } \\
\text { work together to } \\
\text { resolve the existing } \\
\text { problems }\end{array}$ \\
\hline 2. & How to Ask & $\begin{array}{l}\text { Rare to use active } \\
\text { question } \\
\text { After giving a } \\
\text { problem, never give } \\
\text { question to other } \\
\text { students }\end{array}$ & $\begin{array}{l}\text { The teacher has } \\
\text { started to use active } \\
\text { question } \\
\text { After the teacher } \\
\text { give a problem, give } \\
\text { question to other } \\
\text { students }\end{array}$ \\
\hline 3. & $\begin{array}{l}\text { In the learning } \\
\text { process }\end{array}$ & $\begin{array}{l}\text { The teacher rare to } \\
\text { give response to } \\
\text { student's answer } \\
\text { The teacher rare to } \\
\text { give a chance for } \\
\text { students thinking } \\
\text { The teacher does not } \\
\text { give a chance for } \\
\text { students to make } \\
\text { argue }\end{array}$ & $\begin{array}{l}\text { Students have given } \\
\text { a change to respond } \\
\text { other students } \\
\text { answer } \\
\text { Students have given } \\
\text { by the teacher to } \\
\text { make mathematical } \\
\text { thinking } \\
\text { Students have given } \\
\text { a chance by the } \\
\text { teacher to make } \\
\text { argue }\end{array}$ \\
\hline
\end{tabular}

From Table 1 above, one can see the three problems, the experience of a teacher before and after she implement Socio mathematical norm in the classroom. The results of a questionnaire were slightly differenced with observation results. During the learning process, the teacher was not optimal in giving a chance to explore their mathematical thinking. This situation can be seen that the teacher only focuses on what the solution not on why and how to get a solution [9].

\section{CONCLUSIONS}

1. As an initial effort in introducing social norm for teachers through workshop show teachers satisfied in following all activities relating to the social norms in the workshop. This implies teachers realized that they had used some 
activities of social norms such as guiding students to communicate, asking questions and giving argumentation. The teacher constantly made a conscious effort to practice a social norm of sharing responsibility for students to address questions to each other rather than to the teacher.

2. Teachers have more confidence to use social norms in their mathematics classroom. They exercised social norms by asking questions to understand others' ideas, providing explanations to help others understand their strategies, evaluating others' ideas and challenging others' explanations with different cases.

3. During the lesson, the problem that was used not fully able to make students explore their mathematics strategy.

4. In guiding students to use social and Socio mathematical norm, the teachers have made students discuss very well, although the teacher still focuses on mathematics without connected to the context. [18]; [2] referred to the role of teachers in facilitating learning as balancing the tension between "the force of teaching and the freedom of learning."

\section{REFERENCES}

[1] Zulkardi \& Putri, R.I.I., "Pengembangan Blog Support untuk Membantu Siswa dan Guru Matematika Indonesia Belajar Pendidikan Matematika Realistik Indonesia (PMRI)". Jurnal Inovasi Perekayasa Pendidikan (JIPP), vol 2 (1). Pp. 1 - 24, 2010.

[2] Widjaya, W., "Exercising Socio-Mathematical Norms In Classroom Discourse About Data Representation: Insights From One Case Study Of A Grade 6 Lesson In Indonesia”. The Mathematics Educator, vol 13 (2), pp. 21-38, 2012

[3] Depdiknas, Kurikulum Tingkat Satuan Pendidikan Standar Kompetensi SMP dan MTs, Jakarta : Depdiknas, 2006.

[4] Gravemeijer, K. \& Cobb, P., Design Research From The Learning Design Perspective. In Van den Akker, J., Gravemerijer, K., McKenney, S., \& Nieveen, $N$ (Eds.), Educational design research. London: Routledge, 2006.
[5] Bustang, B., Zulkardi, Z., Darmawijoyo, D., Dolk, M., \& van Erde, D., "Developing a Local Instruction Theory for Learning the Concept of Angle through Visual Field Activities and Spatial Representations". International Education Studies, vol 6 (8), pp. 58-70. DOI: 10.5539/ies.v6n8p58, 2013.

[6[ Sembiring, R., Hoogland, K., \& Dolk, M., A Decade of PMRI In Indonesia. Utrecht: APS, 2010.

[7] Putri, R.I.I., "Improving Mathematics Comunication Ability of Students In Grade 2 Through PMRI Approach”. Paper presented in International Seminar and The Fourth National Conference on Mathematics Education UNY, Jogyakarta, 2011.

[8] Risma, D. A., Putri, R. I. I., \& Hartono, Y., “On developing students' spatial visualization ability". International Education Studies, vol 6(9), pp.1-12, 2013.

[9] Zulkardi, Z., Developing a Learning Environment on Realistic Mathematics Education for Indonesian Students Teachers (Enschede: Doctoral Dissertation, University of Twente, 2002.

[10] Gravemeijer, K. Developing Realistic Mathematics Education. Utrecht: CD-b Press. The Netherlands, 1994.

[11] de Lange, J., Assessment: No change without problems. In T.A. Romberg (Ed.), Reform in school mathematics and authentic assessment (pp. 87-172). New York: Suny Press, 1995.

[12] OECD., PISA 2012 Mathematics Framework. Retrieved March 2012, from http://www.oecd.org/dataoecd/8/38/46961598.pdf, 2012.

[13] Mason, Burton and Stacey, Thinking mathematically. Dorchester: Pearson Education Limited. England, 2002.

[14] Gravemeijer, K., Developing Realistic Mathematics Education. Utrecht: CD-b Press. The Netherlands. 1994.

[15] Gravemeijer, K., Realistic Mathematics Education Theory As A Guideline For Problem- Centered, Inter-Active Mathematics Education. In R. K. Sembiring, K. Hoogland \& M. Dolk (Eds.), A decade of PMRI in Indonesia (pp. 41-50). Utrecht: APS International, 2010.

[16] Yackel, E. \& Cobb, P., "Sociomathematical Norms, Argumentation, and Autonomy In Mathematics". Journal for Research in Mathematics Education, vol 27 (4), pp. 458-477, 1996.

[17] Putri, R.I.I. Dolk, M. Zulkardi. 2015. "Professional Development of PMRI Teachers For Introducing Social Norms". IndoMs-JMe: vol. 6., pp. 1 - 15, 2015.

[18] Freudenthal, H., Revisiting mathematics education. China Lectures. Dordrecht: Kluwer Academic Publishers, 1991.

[19] Putri, R.I.I. \& Zulkardi. "Fraction in Shot-Put: A Learning Trajectory". AIP Conference Proceeding 1868, 010001 (2017) http://dx.doi.org/10.1063/1.4995086. 